\title{
Effects of early childhood education attendance on achievement, social skills, behaviour, and stress
}

\author{
Efeitos da permanência na Educação Infantil sobre \\ indicadores de desempenho, habilidades \\ sociais, comportamento e estresse
}

\author{
Marta Regina Gonçalves CORREIA-ZANINI ${ }^{1}$ iD 0000-0003-4776-8917 \\ Edna Maria MARTURANO2 (D) 0000-0002-1545-0093 \\ Anne Marie Germaine Victorine FONTAINE ${ }^{3}$ (iD) 0000-0001-9232-8692
}

\begin{abstract}
There is evidence that Early Childhood Education positively contributes to optimal performance in Elementary School, but there are few studies about its influence on socio-behavioral variables. This study aimed to explore the association between duration of Early Childhood Education attendance (one or two years) and developmental outcomes in the 3rd grade. A total of 151 students from public schools participated in the study and their academic performance, social skills,
\end{abstract}

$\nabla \nabla \nabla$

1 Centro Universitário das Faculdades Associadas de Ensino, Curso de Psicologia, Departamento de Psicologia. R. Matheus Benelli, 1122, Jd. Recreio dos Bandeirantes, 14171-115, Sertãozinho, SP, Brasil. Correspondência para/Correspondence to: M.R.G. CORREIA-ZANINI. E-mail: <psico_marta@yahoo.com.br>.

2 Universidade de São Paulo, Faculdade de Medicina de Ribeirão Preto, Departamento de Neurociências e Ciências do Comportamento. Ribeirão Preto, SP, Brasil.

3 Universidade do Porto, Faculdade de Psicologia e Ciências da Educação, Programa Doutoral em Psicologia. Porto, Portugal. Article based on the doctoral dissertation of M.R.G. CORREIA-ZANINI, entitled "Um estudo prospectivo sobre o percurso escolar de crianças nos primeiros anos do Ensino Fundamental". Universidade de São Paulo, 2013.

Support: Coordenação de Aperfeiçoamento de Pessoal de Nível Superior (process no 5975-11-5), Fundação de Amparo à Pesquisa do Estado de São Paulo (process n ${ }^{\circ} 2014 / 01478-4$ ) and Conselho Nacional de Desenvolvimento Científico e Tecnológico (process $\left.\mathrm{n}^{\circ} 304464 / 2011-2\right)$

Acknowledge: The authors thank the psychologists Jéssica Cristine de Castro, Daniele Ferraz Simões Teixeira, and Cynthia Cassoni for their cooperation during data collection.

$\boldsymbol{\nabla} \boldsymbol{\nabla} \boldsymbol{\nabla}$

Como citar este artigo/How to cite this article

Correia-Zanini, M. R. G., Marturano, E. M., Fontaine, A. M. G. V. (2018). Effects of early childhood education attendance on achievement, social skills, behaviour, and stress. Estudos de Psicologia (Campinas), 35(3), 287-297. http://dx.doi.org/10.1590/1982-02 752018000300007 
externalizing behavior and stress symptoms were assessed. Data analysis comprised group comparison and regression with control of socioeconomic background. The results showed that children who had attended Early Childhood Education for one more year showed better achievement and less stress symptoms. Duration of Early Childhood Education attendance was a significant positive predictor for achievement and a negative one for stress in the 3rd grade. We discuss the quality of Early Childhood Education and its influence on the variables assessed and point to the need for a systematic replication study to assess the generalization of the results.

Keywords: Academic performance; Behavior disorders; Child rearing; Social skills; Stress.

\section{Resumo}

Há evidência de contribuição positiva da Educação Infantil para o desempenho no Ensino Fundamental, mas sobre variáveis sociocomportamentais, os estudos são escassos. Objetivou-se explorar a associação entre tempo de permanência na Educação Infantil (um ou dois anos) e desfechos desenvolvimentais no $3^{\circ}$ ano do Ensino Fundamental. Participaram 151 alunos de escolas públicas, avaliados quanto a: desempenho acadêmico, habilidades sociais, comportamento externalizante e sintomas de estresse. A análise dos dados compreendeu comparação de grupos e regressão com controle do nível socioeconômico. Nos resultados, crianças com um ano a mais de permanência na Educação Infantil apresentaram melhor desempenho e menos sintomas de estresse. O tempo na Educação Infantil foi preditor significativo positivo para o desempenho e negativo para o estresse no $3^{\circ}$ ano do Ensino Fundamental. Discute-se a qualidade da Educação Infantil oferecida e sua influência sobre as variáveis avaliadas, e ressalta-se a necessidade de replicação sistemática do estudo para averiguar a generalização dos resultados.

Palavras-chave: Desempenho escolar; Distúrbios do comportamento; Educação infantil; Habilidades sociais; Estresse.

The impact of school attendance on the lives and development of students is hardly overestimated. Children go to school at an increasingly precocious age. With the universalization of access to Early Childhood Education (ECE), starting at the age of four, the Brazilian children will spend at least one quarter of their awake time at school in contact with educators and peers of the same age, and this occurs during accelerated psychobiological development.

In Brazil, ECE is the first stage of Basic Education, being offered by public or private kindergartens and pre-schools for children from zero to five years of age. According to article 29 from the Lei de Diretrizes e Bases da Educação Nacional (Brasil, 1996, 2013), its purpose is the integral development of small children, considering their physical, psychological, intellectual and social aspects, complementing family and community engagement.

There is evidence that ECE contributes to favorable outcomes in adulthood (Sassi, 2011). International studies indicate a positive effect of ECE on academic performance indicators in elementary education (Burger, 2010; Taggart, Sylva, Melhuish,
Sammons, \& Siraj-Blatchford, 2011). In Brazil, Trivellato-Ferreira and Marturano (2008) found that ECE attendance was associated with better performance at the end of the first grade. Similarly, in a study conducted by Pereira, Marturano, Gardinal-Pizato, and Fontaine (2011), children assessed in the second grade who had had access to ECE obtained better scores in three indicators of school performance: teacher's judgment, a collective test, and an individual standardized test. The effects could not be attributed to differences in variables for economic or educational background of family among the groups, since these variables were controlled. In a longitudinal study, Gardinal-Pizato, Marturano, and Fontaine (2012) controlled the effect of the socioeconomic background and found that access to ECE was associated with a better school performance from the 3rd to the 5 th grade.

Recently, Felício, Terra, and Zoghbi (2012) found effects of ECE on the literacy scores of students in the 2 nd grade. Provinha Brasil was administered in Sertãozinho (SP) together with a socioeconomic questionnaire. The results showed that the literacy scores of students who had attended ECE, aged 3 to 5 years, were about $6 \%$ 
higher than those who had started elementary school at the age of 6 or older.

The effects of ECE on the socioemotional domain are not as clear as in the academic domain. In a survey at English schools described by Taggart et al. (2011), preschool attendance favored sociobehavioral development in the early years of elementary education, and this effect could be observed up to the age of 11 in children who had attended medium and high quality preschool. On the other hand, Keys et al. (2013) did not find any relationship between the quality of preschool and the socioemotional outcomes of children when these were assessed in the 1st grade.

Trivellato-Ferreira and Marturano (2008) found that students in the first grade who had had at least six months of early childhood education, when compared to students who had not had access to this level of education, were considered by the teacher as the most loved by their classmates. The group with no previous experience in ECE had more stress symptoms and perceived school events as more disturbing. More recently, in a follow-up study with children from 3rd to 5th grade, Gardinal-Pizato, Marturano and Fontaine (2014) found a positive effect of ECE on the students' social skills, which were assessed by the teacher, but only for girls. ECE contributed to attenuating (internalizing) emotional problems but did not affect outcomes of (externalizing) behavior problems.

The universalization of access to early childhood education starting at the age of 4 , which is part of Brazil's national public policy, raises the question of the effects of longer time of exposure to $E C E$, that is, the early admission to the formal educational system. There is some evidence of cognitive benefits and controversy regarding socioemotional effects.

In an internationally comprehensive review (Burger, 2010), evidence of increased cognitive development associated with early admission to preschool was not conclusive. In the survey at English schools reported by Taggart et al. (2011), every month of pre-school experience after the age of 2 was associated with better intellectual development, greater independence, concentration and sociability when beginning elementary school. In this study, the positive effect occurred in medium or high quality schools, but not in low quality schools, and school/cognitive outcomes were more evident than social behavioral development. Morrissey (2010) also found benefits for cognitive development in North American children, associated with early admission to ECE, as of the age of 3 years, but did not identify socioemotional effects. However, in the study of Coley, Votruba-Drzal, Miller, and Koury (2013), children who had started pre-school earlier showed more externalizing behavior in the first year of elementary school.

Brazilian researchers also found mixed results. Felício et al. (2012), focusing on school performance of 2 nd graders, identified a small advantage in the academic outcomes of students who had attended early childhood education. Marturano and Gardinal-Pizato (2015) did not find any differences regarding academic abilities, social skills or behavior problems of 3rd graders who attended ECE for one or two years. Pereira et al. (2011) found that 3rd graders who had attended ECE for two years did not have more social skills, but received more reciprocal choices in a sociometric test when compared with peers who attended ECE for one year. Other studies did not detect differences related to the time spent in $E C E$, either in the cognitive (Gardinal-Pizato et al., 2012) or socioemotional domain (Gardinal-Pizato et al., 2014).

Research on the effects of duration of ECE attendance has methodological challenges. One of them is related to the possible differences among families of children who started ECE earlier or later: children from higher socioeconomic families tend to start school earlier (Felício et al., 2012; Gardinal-Pizato et al., 2012), which introduces a confounding factor between the effects of Socioeconomic Background (SEB) and duration of ECE attendance. Another challenge, also related to the socioeconomic factor, is the influence of the diverse student population in school, which can determine differences among students from schools located in more or less privileged areas (Aikens \& Barbarin, 2008; Marturano \& Gardinal-Pizato, 2015). 
Taking these challenges into account, the present study focused on the effects of duration of ECE attendance on children's academic and socioemotional outcomes in elementary school. With the purpose of contributing to the discussion of the above-mentioned controversial aspects, the aim of the study was to investigate the association between duration of ECE attendance and behavior outcomes in 3rd graders concerning the academic and socioemotional domains. The interest in focusing on 3rd graders derives from research results suggesting that students at this school level overcome the transition between early childhood education and elementary education (Correia-Zanini \& Marturano, 2016). The outcomes considered were academic performance, social skills, externalizing behavior problems, and stress symptoms. Early childhood education was assessed considering attendance (one or two years). The effects of the three influential factors on the development of the child were as follows: SEB (Burger, 2010), location of the elementary school as an indicator of the socioeconomic background of the student (Aikens \& Barbarin, 2008), and gender (Grimm, Steele, Mashburn, Burchinal, \& Pianta, 2010; Reynolds, Sander, \& Irvin, 2010).

\section{Method}

\section{Participants}

A total of 151 children, 79 boys and 72 girls, aged 8 years and 1 month to 9 years and 4 months (mean 8.7 years), who attended the 3rd grade of elementary school in municipal public schools in a city in the state of São Paulo participated in the study. Nineteen of them had attended ECE for one year and 132 for two years. Their teachers were also interviewed $(n=33)$.

\section{Location}

The research was part of a longitudinal follow-up study that collected data from the students during $1 \mathrm{st}, 2$ nd and 3rd grade. The collection occurred in seven of the 15 municipal elementary schools of Sertãozinho, state of São Paulo, with approximately 111 thousand inhabitants. The selection of schools was carried out together with the education department of the municipality, aiming to represent different areas, one school in the downtown area, two near the downtown area and four in more distant neighborhoods, totaling 25 classes.

At the time of data collection, the history of municipal investment in ECE was higher than the national average $(R \$ 1,761$ between 2005 and 2006, compared to the national average of $\mathrm{R} \$ 1,196$, according to Felício et al. (2012). All elementary schools obtained a higher score in the Índice de Desenvolvimento da Educação Básica (IDEB, Basic Education Development Index) than the national and state averages.

\section{Instruments and measurements}

In order to assess academic performance, the Provinha Brasil, version 2009, developed by the Instituto Nacional de Estudos e Pesquisas Educacionais Anísio Teixeira (2009), was administered with the purpose of diagnosing the literacy level of children enrolled in the 2 nd grade. The respondents were the students themselves and application was collective. The instrument contains one example of the question that shows students how to answer the test and 24 multiple-choice questions to assess performance. Performance assessment questions are arranged in increasing order of skill requirements, from the most basic to the most advanced. One point is assigned for each correct answer. For this research, the test was expanded to include adequate questions to assess the 3rd graders, as stated by Correia-Zanini (2013).

The Social Skills Rating System (SSRS-BR), teacher's version (Bandeira, Del Prette, Z.A.P., Del Prette, \& Magalhães, 2009) was used to assess social skills and behavior problems, whose structure allows the measuring of social skills, behavior problems and academic competence of students aged 6 to 12. For social skills and behavior problems, the teacher had to indicate how often 
the student shows certain skills and behavior: never (0 point), sometimes (1 point) or always (2 points). In the present study, the scales for externalizing behavior problems and social behavior were used and item composition was defined by confirmatory factor analysis on the original research sample (Correia-Zanini, 2013). The internal consistency indexes were satisfactory: Social Skills $(a=0.85)$, Externalizing $(\alpha=0.901)$ and Internalizing $(\alpha=0.786)$ Behavior Problem.

The Child Stress Scale (CSS) (Lipp \& Lucarelli, 2008) was also used, which aims to identify the frequency that children from 6 to 14 years old experience stress symptoms and in which stage they are (no stress, alert stage, resistance stage, stage close to exhaustion or exhaustion). It is composed of 35 items on a 0-4-point Likert-type scale, grouped into four factors: physical reactions, psychological reactions, psychological reactions with a depressive component, and psychophysiological reactions. Its application can be collective or individual. For each item the child should paint the quadrants of a circle indicating how often a particular symptom occurs (it never happens - no quadrant; it happens a little - one quadrant; it happens sometimes - two quadrants; it almost always happens - three quadrants; it always happens - four quadrants). Based on the score of the items, the symptoms are classified into one of five stages. For this study the total gross value was used. The scale with the original sample obtained $\alpha=0.90$, and with this sample $\alpha=0.89$ was obtained, which was considered satisfactory.

For the SEB survey of the family, the Critério Brasil (Associação Brasileira de Empresas de Pesquisa, 2010) was used. It is composed of 11 items, of which nine assess the number of durable goods of the family, one assesses the level of education of the head of the family, and one assesses the number of monthly workers in the household, which were stratified into quintiles: A (highest SEB), B, C, D and E.

The duration of ECE attendance was measured in terms of annual cycles completed by the child in preschool. The child could have completed only phase 2 (one year) or phase 1 and phase 2 (two years).
The location of the elementary school, as an indicator of the SEB of its students, was indicated in two broad categories. The first one included the schools in the downtown area and near the downtown area of the city and the second one included the schools located in the suburbs.

\section{Procedures}

This research is part of a project approved by the Comitê de Ética em Pesquisa at Faculdade de Filosofia, Ciências e Letras de Ribeirão Preto (Process no 528/2010 - 2010.1.1794.59.2). It complies with the guidelines of Resolution $n^{\circ} 196 / 96$ of Comissão Nacional de Ética em Pesquisa (CONEP, National Commission of Ethics en Researche) and Resolution n ${ }^{\circ}$ 016/2000 of the Conselho Federal de Psicologia (Federal Board of Psychology). The adultparticipants signed an Informed Consent Form (ICF); and the guardian of the child-participant signed an ICF and the child gave his/her verbal consent.

Information on the duration of ECE attendance was obtained by consulting the record of enrollment on the website of the Companhia de Processamento de Dados do Estado de São Paulo (PRODESP, Data Processing Company of the State of São Paulo), with the assistance of a school secretary. This information was confirmed in an interview with one of the guardians of 107 children (the mother in $91 \%$ of cases) at the beginning of the research. During the interview, the Critério Brasil was administered.

Data collection with the children and the teachers took place between September and December 2012. The data were collected during class time at spaces assigned by the schools. The children answered the instruments individually, the same ones that had been administered during the larger project, including the CSS. Provinha Brasil was administered collectively by Correia-Zanini with the help of an assistant. The teachers were asked to fill out the SSRS forms. They were provided with an email and telephone in case of doubts, and a deadline was agreed for the return of the forms. 


\section{Analysis procedure}

The Statistical Package for Social Sciences (SPSS) program, version 19, was used to analyze the data. Initially, two groups were formed based on the duration of ECE attendance: G1 was composed of 19 children who had attended ECE for one year and $G 2$ was composed of 132 children who had attended ECE for two years. The chi-square test was used to verify if the groups were equal regarding the variables gender, age, school location and SEB. No differences were found in the gender variables $\left(\chi^{2}=0.909 / \mathrm{gL}=1 ; p=0.340\right)$, age $\left(\chi^{2}=1.480 / \mathrm{gL}=1\right.$; $p=0.224)$ and school location $\left(\chi^{2}=3.776 / \mathrm{gL}=2\right.$; $p=0.151)$. As for SEB, G2 presented a more favorable distribution than $\mathrm{G} 1\left(\chi^{2}=11.399 / \mathrm{gL}=2 ; p=0.003\right)$.

Once the groups were formed, the values of kurtosis and symmetry were verified for each variable. All values found were lower than seven and three, respectively, which, according to Kline (Marôco, 2011) can be submitted to parametric statistical analyses. Thus, for comparison between groups, Student's $t$ test was used, considering significant values those with $p \leq 0.05$. To assess the magnitude of differences, effect was considered small when $d \leq 0.2$; medium when $d$ ranged from 0.2 to 0.5 ; high when $d$ was between 0.50 and 1 ; very high when $d>1$ (Marôco, 2011).

To predict academic performance, social skills, behavior problems, and stress symptoms, multiple linear regression analysis was conducted on the data of 107 children with available SEB information. This sample aliquot did not differ from the total sample concerning gender ( 56 boys and 51 girls), age (mean 8.9 years) and duration of ECE attendance (11 for one year, 98 for two years). Thirty-six children studied in schools in the downtown area or near the downtown area and 71 in suburb schools.

Hierarchical multiple regression analysis was used. The socio-demographic predictors were included in the first block - gender and SEB; the duration of ECE attendance was included in the second block and the location of the elementary school in the third. The categorical variables gender, duration of ECE attendance and location of the elementary school were transformed into dummy variables. For gender, the coding was 0 for boys and 1 for girls; one year of ECE attendance was assigned 0 and two years, 1 . As for the location of the school, 0 corresponded to not being located in the suburb and 1 corresponded to being located in the suburb.

Durbin Watson statistics was used to verify the independence of residues, with acceptable values between 1.6 and 2.4 (Marôco, 2011). Collinearity was detected using Variance Inflation Factor (VIF) and no variables suggested assumption violation.

\section{Results}

The results of the group comparison with all participants, G1 and G2, are shown in Table 1. The mean academic performance of the 3rd graders was higher for those who attended ECE for two years than the students who attended ECE for one year, whom presented more stress symptoms on average. The effect size was high for both differences. No significant differences were observed in the other variables.

The results of the multiple linear regression analysis for predicting academic performance and social skills are shown in Table 2 . In the predictive model of academic performance, the variables comprising the first block account for the variation of $16 \%$ obtained in the 3rd grade, of which gender and SEB are significant, the latter with a higher regression coefficient $(\beta=0.318)$. When adding the ECE to the model (block 2), the explanatory power increased by 0.04 , explaining the variation of $20 \%$, and the three predictive variables were significant, but SEB still presented the highest regression coefficient, followed by gender and ECE. The third model, which included the location of the school, explained the variation of $21 \%$. In this model, the variable with the highest regression coefficient was gender, followed by the SEB and ECE attendance. School location was not a significant predictor of academic performance.

For the prediction of social skills, the first model explains the variation of $9 \%$, with gender 
Table 1

Group comparisons between one or two years of ECE attendance

\begin{tabular}{|c|c|c|c|c|c|c|}
\hline \multirow{2}{*}{ Variable } & \multicolumn{2}{|c|}{ G1 $(n=19)$} & \multicolumn{2}{|c|}{$\mathrm{G} 2(\mathrm{n}=132)$} & \multirow{2}{*}{$t$} & \multirow{2}{*}{$D$} \\
\hline & $M$ & $S D$ & M & $S D$ & & \\
\hline Academic performance & 19.74 & 4.72 & 23.16 & 4.27 & $-2.987^{*}$ & 0.76 \\
\hline Social skills & 32.53 & 13.65 & 36.29 & 10.96 & -1.356 & 0.30 \\
\hline Externalizing BP & 4.63 & 3.42 & 4.45 & 3.93 & 0.216 & 0.05 \\
\hline Internalizing BP & 3.32 & 3.25 & 2.42 & 2.26 & 1.156 & 0.32 \\
\hline Stress symptoms & 53.16 & 25.33 & 39.24 & 20.85 & $2.285^{*}$ & 0.60 \\
\hline
\end{tabular}

Note: ${ }^{*} p<0.05$.

G1: Group attended ECE for one year; G2: Group attended ECE for two years; D: Cohen Coefficient; BP: Behavior Problems; ECE: Early Childhood Education; SD: Standard Deviation; M: Median.

Table 2

Hierarchical linear regression to examine predictors of academic performance and social skills of 3rd graders

\begin{tabular}{|c|c|c|c|c|c|c|c|c|c|c|}
\hline \multirow{2}{*}{ Predictors } & \multicolumn{5}{|c|}{ Academic performance } & \multicolumn{5}{|c|}{ Social skills } \\
\hline & $B$ & $(S E)$ & $\beta$ & $R^{2}$ & $\Delta R^{2}$ & B & $(S E)$ & $\beta$ & $R^{2}$ & $\Delta R^{2}$ \\
\hline \multicolumn{11}{|l|}{ Block 1} \\
\hline Gender & 1.91 & $(0.71)$ & $0.24^{*}$ & & & 6.50 & $(2.06)$ & $0.30^{* *}$ & & \\
\hline SEB & 0.20 & $(0.06)$ & $0.32^{* * *}$ & & & 0.02 & $(0.17)$ & 0.01 & & \\
\hline$F(2.106)$ & \multicolumn{2}{|c|}{$9.754^{* * *}$} & & 0.16 & 0.16 & \multicolumn{2}{|c|}{$4.998^{* *}$} & & 0.09 & 0.09 \\
\hline \multicolumn{11}{|l|}{ Block 2} \\
\hline Gender & 2.18 & $(0.70)$ & $0.28^{* *}$ & & & 7.12 & $(2.07)$ & $0.32^{* * *}$ & & \\
\hline SEB & 0.18 & $(0.06)$ & $0.28^{* *}$ & & & -0.03 & $(0.17)$ & -0.02 & & \\
\hline ECE & 2.66 & $(1.18)$ & $0.21^{*}$ & & & 6.15 & $(3.45)$ & $0.17^{\dagger}$ & & \\
\hline$F(3.106)$ & \multicolumn{2}{|c|}{$8.459^{* \star *}$} & & 0.20 & 0.04 & \multicolumn{2}{|c|}{$4.458^{* *}$} & & 0.11 & 0.03 \\
\hline \multicolumn{11}{|l|}{ Block 3} \\
\hline Gender & 2.21 & $(0.70)$ & $0.28^{* *}$ & & & 7.13 & $(2.08)$ & $0.33^{* * *}$ & & \\
\hline SEB & 0.15 & $(0.06)$ & $0.23^{*}$ & & & -0.04 & $(0.19)$ & -0.03 & & \\
\hline ECE & 2.61 & $(1.17)$ & $0.20^{*}$ & & & 6.13 & $(3.47)$ & $0.17^{\dagger}$ & & \\
\hline Location & -0.98 & $(0.81)$ & -0.12 & & & -0.35 & (2.39) & -0.06 & & \\
\hline$F(5.106)$ & \multicolumn{2}{|c|}{$6.744^{* * *}$} & & 0.21 & 0.01 & \multicolumn{2}{|c|}{$3.317^{*}$} & & 0.11 & 0.00 \\
\hline Durbin Watson & \multicolumn{2}{|c|}{1.952} & & & & \multicolumn{2}{|c|}{1.836} & & & \\
\hline
\end{tabular}

Note: ${ }^{*} p \leq 0.05 ;{ }^{* *} p \leq 0.01 ;{ }^{* * *} p<0.001 ;{ }^{* * *}{ }^{\dagger} p \leq 0.10$.

N: 106. B: Non-Standard Regression Coefficient; SE: Standard Error; $\beta$ : Standardized Regression Coefficient; $R^{2}$ : Coefficient of Association between the Predictive and Predicted Variables; $\Delta R^{2}$ : Coefficient that Indicates the Change in $R^{2}$ by Introducing New Block of Variables; ECE: Early Childhood Education; Location: school location; SEB: Socioeconomic Background.

being the only variable with a significant coefficient. An increase of $3 \%$ was found in the second model in comparison with the first one; gender remained a significant predictor and duration of ECE attendance was marginally significant $(p=0.078)$. With the introduction of the variable school location in the third block, there was no increase in the percentage of variation of the social skill results explained by the model; being a girl remained the best predictor of social skills in the 3rd grade.

Table 3 shows the prediction models for externalizing behavior problems and stress 
Table 3

Hierarchical regression analyses to examine predictors of behavior problems and stress symptoms in the 3rd grade

\begin{tabular}{|c|c|c|c|c|c|c|c|c|c|c|}
\hline \multirow{2}{*}{ Predictors } & \multicolumn{5}{|c|}{ Externalizing behavior problems } & \multicolumn{5}{|c|}{ Stress symptoms } \\
\hline & B & $(S E)$ & $\beta$ & $R^{2}$ & $\Delta R^{2}$ & B & $(S E)$ & $\beta$ & $R^{2}$ & $\Delta R^{2}$ \\
\hline \multicolumn{11}{|l|}{ Block 1} \\
\hline Gender & -2.55 & $(0.67)$ & $-0.35^{* *}$ & & & 2.71 & $(3.91)$ & 0.07 & & \\
\hline SEB & -0.07 & $(0.05)$ & -0.13 & & & -0.31 & $(0.32)$ & -0.10 & & \\
\hline$F(2.106)$ & \multicolumn{2}{|c|}{$8.145^{* *}$} & & 0.14 & 0.14 & \multicolumn{2}{|c|}{0.732} & & 0.01 & 0.01 \\
\hline \multicolumn{11}{|l|}{ Block 2} \\
\hline Gender & -2.69 & $(0.67)$ & $-0.37^{* *}$ & & & 1.16 & $(3.88)$ & 0.03 & & \\
\hline SEB & -0.06 & $(0.05)$ & -0.10 & & & -0.18 & $(0.32)$ & -0.05 & & \\
\hline ECE & -1.37 & $(1.13)$ & -0.11 & & & -15.30 & $(6.49)$ & $-0.23^{*}$ & & \\
\hline$F(3.106)$ & \multicolumn{2}{|c|}{$5.948^{* *}$} & & 0.15 & 0.01 & \multicolumn{2}{|c|}{$2.363^{\dagger}$} & & 0.06 & 0.05 \\
\hline \multicolumn{11}{|l|}{ Block 3} \\
\hline Gender & -2.72 & $(0.67)$ & $-0.37^{* *}$ & & & 0.85 & $(3.81)$ & 0.02 & & \\
\hline SEB & -0.03 & $(0.06)$ & -0.05 & & & 0.14 & $(0.34)$ & 0.04 & & \\
\hline ECE & -1.33 & $(1.13)$ & -0.11 & & & -14.86 & $(6.37)$ & $-0.22^{*}$ & & \\
\hline Location & 1.03 & $(0.77)$ & 0.13 & & & 9.82 & (4.39) & $0.23^{*}$ & & \\
\hline$F(5.106)$ & \multicolumn{2}{|c|}{$4.936^{* *}$} & & 0.16 & 0.01 & \multicolumn{2}{|c|}{$3.093^{*}$} & & 0.11 & 0.05 \\
\hline Durbin Watson & \multicolumn{2}{|c|}{2.043} & & & & \multicolumn{2}{|c|}{2.367} & & & \\
\hline
\end{tabular}

Note: ${ }^{*} p \leq 0.05 ;{ }^{* *} p \leq 0.01 ;{ }^{\dagger} p \leq 0.10$.

N: 106. B: Non-Standard Regression Coefficient; SE: Standard Error; $\beta$ : Standardized Regression Coefficient; $R^{2}$ : Coefficient of Association between the Predictive and Predicted Variables; $\Delta R^{2}:=$ Coefficient indicating the Change in $\mathrm{R}^{2}$ by Introducing a New Block of Variables; ECE: Early Childhood Education; Location: School location; SEB: Socioeconomic Background.

symptoms. The only significant predictor for externalizing behavior problems was gender. The model with the demographic variables explains the variation of $14 \%$ with a $1 \%$ increase in the second and third blocks, thus the final model explained the variation of $16 \%$ of the results, associated with the male gender.

For stress symptoms, according to Table 3, the first block (gender and SEB) was not significant. By adding duration of ECE attendance, this variable presented a significant and negative regression coefficient, but the model was marginally significant $(p=0.076)$. In the third block, with the inclusion of the school location, the model becomes significant, explaining the variation of $11 \%$ of the symptoms. School location is the best predictor, showing a positive coefficient, followed by duration of ECE attendance, which showed a negative coefficient.

\section{Discussion}

This study was motivated by the following question: would longer ECE attendance be a predictor of better school adaptation in elementary school based on academic and socioemotional indicators? The aim of this study was to verify if duration of early childhood education attendance would be associated with indicators of academic performance, social skills, externalizing behavior problems and stress symptoms in the 3rd grade. Therefore, two methodological strategies were used. The first compared groups of children who had attended ECE for one or two years; the second used regression models controlling the variables whose effects could be confounded with ECE effects, since they were associated with different developmental outcomes in elementary school.

In the group comparisons, two positive results were found: children with an additional 
year in ECE showed better performance and less stress symptoms in the 3rd grade. No difference was detected for social skills and externalizing behavior problems.

The first positive result, indicating better academic performance for children who attended ECE longer, corroborates previous studies conducted in Brazil (Felício et al., 2012; Marturano \& Gardinal-Pizato, 2015) and in England (Taggart et al., 2011). The results seem to be robust since the effect size was large and the association was maintained in the regression analysis, which included three potentially confounding variables - gender, SEB, and school location.

Considering that this relation has not always been found (Burger, 2010; Gardinal-Pizato et al., 2012; Pereira et al., 2011), the results may be associated with the quality of the preschool, as Burger (2010) and Taggart et al. (2011) have pointed out. Although there is no objective data on the quality of ECE in the municipality, information on ECE investment, which is above the national average (Felício et al., 2012), and IDEB of the elementary schools, higher than the state average, indicate a well-structured municipal education network. Burger (2010), in his review on the effects of pre-school education on cognitive development, which is primarily assessed by school results, concludes that high-quality early childhood experiences may play a more crucial role than the age of admission into ECE, intensity or duration of the program.

The second positive result indicated that children who attended ECE for two years presented, on average, less stress symptoms in the third grade when compared with their peers who attended ECE for one year. Analogously to what was found concerning academic performance, the results regarding the effect of ECE attendance on stress symptoms in the 3rd grade were also robust. The effect size when comparing the groups was large and the regression analysis indicated a significant effect of ECE in the presence of the variables gender, SBE and location of the elementary school.

This is an unprecedented result, as this relation has not been discussed in the literature.
In a single previous study, Trivellato-Ferreira and Marturano (2008) investigated the effect of ECE attendance, noting the protective effect of ECE on the level of stress symptoms in the 1st grade using the Child Stress Scale. In that study, ECE attendance was also associated with lower perception of school-related stressful situations, a result that reaffirms the protective effect of ECE.

Here, a distinction between the two studies should be drawn concerning the differences between the first and third grade. On the one hand, because transition to first grade is considered a potentially stress-inducing event (Marturano, 2008), first graders may present more stress symptoms than students in more advanced grades, as found by Lipp, Arantes, Buriti, \& Witzig (2002). On the other hand, in the third grade, according to recent research, children show signs of overcoming the challenges of elementary school transition, presenting the lowest levels of stress since school admission (Correia-Zanini \& Marturano, 2016). In view of these findings, it is noteworthy that longer ECE attendance is still protective against stress in the third grade. Replication studies are required to verify the degree of generalization of these results.

The regression models, which included predictors of gender and SBE as well as school location, were adequate, albeit with modest predictive power of developmental outcomes. Predictor configuration was generally consistent with the literature.

For academic performance, assessed by Provinha Brasil, the final model explained $21 \%$ of individual differences. In addition to duration of ECE attendance, gender and SEB are included in the model, indicating that girls and children from a higher socioeconomic background showed better school performance. Two previous longitudinal studies indicated similar results at the beginning of elementary education, but gender differences were diluted in the more advanced grades, while the effect of SEB increased (Aikens \& Barbarin, 2008; Grimm et al., 2010).

Converging with the results of previous research, which pointed out that girls present more social skills during the first years of elementary 
school (Reynolds et al., 2010) and boys more externalizing behavior (Silver, Measelle, Armostrong, \& Essex, 2010), gender was the only predictor of social skills and externalizing problems in the 3rd grade, explaining the variation of $9 \%$ and $16 \%$ in the respective results. For social skills, a positive association with the duration of ECE attendance was observed as a trend, whose entry into the regression model increased the explanatory power by $2 \%$.

Stress symptoms in 3rd graders were the only outcome explained by the school variables, excluding the socio-demographic indicators of the child. By explaining the variation of $11 \%$ in the stress level, the duration of ECE attendance behaved as a protective factor, while the location of the elementary school in the suburb was a risk factor for stress in the 3rd grade. It should also be noted that the school location was not associated with any other outcome. These results emphasize, on the one hand, stress as a situational process, dependent on context and, on the other hand, the vulnerability of children to school-related stressors, requiring that the school be a major focus of research about the factors that influence child stress during elementary school years.

The limitations of study should be pointed out. One of them was the reduced number of children who had attended ECE for one year. This condition may have contributed to a reduced sensitivity of the statistical tests, especially when comparing the groups. The measure used as estimate of the school population SEB in elementary school may also be cited as a limitation, since the geographical location of the schools in the municipality is a rough indicator, which may not adequately reflect the condition that was intended to be evaluated. It should be noted, however, that these two limitations do not invalidate the results, as they weaken the effects that could have been detected with greater accuracy if they had been corrected.

When investigating whether longer ECE attendance would be predictive of better school adjustment of the child in elementary school, the attendance was associated with better performance in a national reading assessment and lower level of stress reported by the child. In addition, the association between longer ECE attendance and poorer behavioral outcomes, found in previous studies, at the beginning of elementary school was not replicated (Coley et al., 2013). The results related to stress symptomatology are an original contribution, suggesting not only a protective effect associated with earlier admission to ECE, but also the need to take the elementary school context into account when considering the children's emotional health.

\section{Contributors}

All authors contributed in the research that originated the article. M.R.G. CORREIA-ZANINI conducted the analysis of the data, wrote the method and results and revised the first version. E.M. MARTURANO contributed to the idealization of the article, bibliographical survey, wrote the introduction and discussion of the results. A.M.G.V. FONTAINE interpreted the results and revised the final version.

\section{References}

Aikens, N. L., \& Barbarin, O. (2008). Socioeconomic differences in reading trajectories: The contribution of family, neighborhood, and school contexts. Journal of Educational Psychology, 100(2), 235-251. http:// dx.doi.org/10.1037/0022-0663.100.2.235

Associação Brasileira de Empresas de Pesquisa (Brasil). (2010). Critério de classificação econômica Brasil. Recuperado em fevereiro 22, 2010, de http://www. abep.org.br

Bandeira, M., Del Prette, Z. A. P., Del Prette, A., \& Magalhães, T. (2009). Validação das escalas de habilidades sociais, comportamentos problemáticos e competência acadêmica (SSRS-BR) para o ensino fundamental. Psicologia: Teoria e Pesquisa, 25(2), 271-282. http://dx.doi.org/10.1590/S0102-37722009 000200016

Brasil. (1996, 23 de dezembro). Lei no 9.394. Estabelece as Diretrizes e Bases da Educação Nacional. Recuperado em setembro, 13, 2016, de http://www. planalto.gov. br/ccivil_03/leis/L9394.htm

Brasil. (2013, 4 de abril). Lei no 12.796. Estabelece as Diretrizes e Bases da Educação Nacional. Recuperado em setembro 13, 2016, de http://www. planalto. gov.br/ccivil_03/_Ato2011-2014/2013/Lei/L12796. htm\#art1 
Burger, K. (2010). How does early childhood care and education affect cognitive development? An international review of the effects of early interventions for children from different social backgrounds. Early Childhood Research Quarterly, 25(2), 140-165. http:// dx.doi.org/10.1016/j.ecresq.2009.11.001

Coley, R. L., Votruba-Drzal, E., Miller, P. L., \& Koury, A. (2013). Timing, extent, and type of child care and children's behavioral functioning in kindergarten. Developmental Psychology, 49(10), 1859-1873. http:// dx.doi.org/10.1037/a0031251

Correia-Zanini, M. R. G. (2013). Um estudo prospectivo sobre o percurso escolar de crianças nos três primeiros anos do Ensino Fundamental (Tese de doutorado nãopublicada). Universidade de São Paulo, Ribeirão Preto. Recuperado em maio, 23, 2018, de http://www.teses. usp.br/teses/disponiveis/59/59137/tde-06012014-10 0239/pt-br.php

Correia-Zanini, M. R. G., \& Marturano, E. M. (2016). Getting started in elementary school: Cognitive competence, social skills, behavior, and stress. PsicoUSF, 21(2), 305-317.

Felício, F., Terra, R., \& Zoghbi, A. C. (2012). The effects of early childhood education on literacy scores using data from a new Brazilian assessment tool. Estudos Econômicos, 42(1), 97-128. http://dx.doi.org/10.1590/ S0101-41612012000100004

Gardinal-Pizato, E. C., Marturano, E. M., \& Fontaine, A. M. G. V. (2012). Acesso à educação Infantil e trajetórias de desempenho escolar no ensino fundamental. Paidéia, 22(52), 187-196. http://dx.doi.org/10.1590/ S0103-863X2012000200005

Gardinal-Pizato, E. C., Marturano, E. M., \& Fontaine, A. M. G. V. (2014). Trajetórias de habilidades sociais e problemas de comportamento no ensino fundamental: influência da educação infantil. Psicologia: Reflexão e Crítica, 27(1), 189-197. http://dx.doi.org/10.1590/s0 102-79722014000100021

Grimm, K. J., Steele, J. S., Mashburn, A. J., Burchinal, M., \& Pianta, R. C. (2010). Early behavioral associations of achievement trajectories. Developmental Psychology, 46(5), 976-983. http://dx.doi.org/10.1037/a0018878

Instituto Nacional de Estudos e Pesquisas Educacionais Anísio Teixeira (Brasil). (2009). Provinha Brasil: guia de aplicação. Recuperado em junho 11, 2018, de http:// portal.inep.gov.br/web/guest/materiais-de-aplicacao

Keys, T. D., Farkas, G., Burchinal, M. R., Duncan, G. J., Vandell, D. L., Li, W., ... Howes, C. (2013). Preschool downtown quality and school readiness: quality effects and variation by demographic and child characteristics. Child Development, 84(4), 1171-1190. http://dx.doi. org/10.1111/cdev.12048amrturan

Lipp, M. E. N., \& Lucarelli, M. D. M. (2008). Escala de Stress Infantil (ESI): manual. São Paulo: Casa do Psicólogo.
Lipp, M. E. N.; Arantes, J. P.; Buriti, M. S., \& Witzig, T. T. (2002). O estresse em escolares. Psicologia Escolar e Educacional, 6(1), 51-56. http://dx.doi.org/10.1590/ S1413-85572002000100006

Marôco, J. (2011). Análise estatística com o SPSS Statistics (5a. ed.). Pêro Pinheiro, Portugal: ReportNumber.

Marturano, E. M. (2008). Tensões cotidianas na transição da primeira série: um enfoque de desenvolvimento. Psicologia em Estudo, 13(1), 77-85. http://dx.doi. org/10.1590/S1413-73722008000100010

Marturano, E. M., \& Gardinal-Pizato, E. C. (2015). Preditores de desempenho escolar no $5^{\circ}$ ano do ensino fundamental. Psico, 46(1), 16-24. http://dx.doi.org/10. 15448/1980-8623.2015.1.14850

Morrissey, T. W. (2010). Sequence of child care type and child development: What role does peer exposure play? Early Childhood Research Quarterly, 25(1), 33-50. http://dx.doi.org/10.1016/j.ecresq.2009.08.005

Pereira, M. T., Marturano, E. M., Gardinal-Pizato, E. C., \& Fontaine, A. M. G. V. (2011). Possíveis contribuições da educação infantil no desempenho e competência social de escolares. Psicologia Escolar e Educacional, 15(1), 101-109. http://dx.doi.org/10.1590/\$1413-85 572011000100011

Reynolds, M. R., Sander, J. B., \& Irvin, M. J. (2010). Latent curve modeling of internalizing behaviors and interpersonal skills through elementary school. School Psychology Quarterly, 25(4), 189-201. http://dx.doi. org/10.1037/a0021543

Sassi, R. B. (2011). Got a Raise? Thank your kindergarten teacher. Journal of the American Academy of Child and Adolescent Psychiatry, 50(1), 1-2. http://dx.doi. org/10.1016/j.jaac.2010.10.003

Silver, R. B., Measelle, J. R., Armstrong, J. M., \& Essex, M. J. (2010). The impact of parents, child care providers, teachers, and peers on early externalizing trajectories. Journal of School Psychology, 48(6), 555-583. http:// dx.doi.org/10.1016/j.jsp.2010.08.003

Taggart, B., Sylva, K., Melhuish, E., Sammons, P., \& SirajBlatchford, I. (2011). O poder da pré-escola: evidências de um estudo longitudinal na Inglaterra. Cadernos de Pesquisa, 41(142), 68-87. http://dx.doi.org/10.1590/ S0100-15742011000100005

Trivellato-Ferreira, M. C., \& Marturano, E. M. (2008). Recursos da criança, da família e da escola predizem competência na transição da $1^{\text {a }}$ série. Revista Interamericana de Psicologia, 42, 407-410. Recuperado em maio, 23, 2018, de http://pepsic.bvsalud.org/scielo.php?script=sci_arttext \&pid=S0034-96902008000300015

Received: March 22, 2016

Final version: December 14, 2016

Approved: February 15, 2017 